\title{
ゴム弾性舗装の弾力性と低騒音性に関する検討
}

\author{
小林昭則 ${ }^{1}$, 平川一成 ${ }^{2}$, 島 広志 $^{3}$, 丸山暉彦 ${ }^{4}$ \\ ${ }^{1}$ 正会員 大成ロテック(株)生産技術本部技術部( † 365-0027 鴻巣市上谷 1456 ) \\ 2 正会員工修 大成ロテック(株)生産技術本部技術研究所( ⿳ 365-0027 鴻巣市上谷 1456) \\ ${ }^{3}$ 正会員＼cjkstart博(工) (株) ブリヂストン研究開発本部( † 187-8531 小平市小川東町 3-1-1) \\ ${ }^{4}$ 正会員 工博 長岡技術科学大学 環境・建設系 教授 ( ₹ 940-2188 長岡市上富岡町 1603-1)
}

\begin{abstract}
ゴム弾性舗装は, 従来の排水性舖装より高い騒音低減効果が得られ, 弚の騒音低減効果は, 舗装体 の吸音性，軟らかさ，衝撃吸収性およびこれらに影響を及ぼす舗装厚等に影響を受けると考えられる． 今回, 車両走行騒音, ショッピングカート騒音に及ぼす要因として後者の”衝撃吸収性”を取りあげ, 室内試験ではゴム弾性舗装の衝撃加速度とタイヤ落下衝突音について, 試験施工では衝撃加速度と普 通車騒音および静的ばね定数とショッピングカート振動との関連について検討した . 产の結果, ゴム 弾性舗装の衝撃加速度および静的ばね定数は, 車両走行騷音やショッピングカート振動と密接な関係 にあることを確認した .
\end{abstract}

Key Words : rubber elastic pavements, elasticity, spring constant, impulsive acceleration, tire/road noise

\section{1 .はじめに}

タイヤリサイクルゴムチップ(以下 , ゴムチップと いう)を主要材料に用いた多孔質なゴム弾性舗装は， ゴムチップと細骨材とバインダによる混合物を現位置 で製造，敷設した舗装で，従来の排水性舗装より高い 騒音低減効果を有し，効果の持続性も排水性舗装より 長くなることが知られてる ${ }^{1), 21}$. また, 多孔質なゴム 弾性舗装は, 速度 $30 \mathrm{~km} / \mathrm{h}$ 以下の低速走行騒音も大幅 に低減できるとともに, 普通車相当の騒音源であるシ ヨッピングカート騒音も大幅に低減できることが明ら かになっている ${ }^{3)}$.これまでの研究から，ゴム弾性舗 装の低騒音性は, 舗装体の吸音性, 軟らかさ, 衝撃緩 和性およびこれらに影響を及ぼす舗装厚などと密接な 関係があると考えられるが，これら要因と低騒音性の 関係は明らかになっていない．

今回, ゴム弾性舗装の軟らかさと衝撃吸収性( 以降, これらを併せて弾力性と称す)に着目し，室内試験お よび試験施工から普通車走行騒音, ショッピングカー 卜騒音と弾力性の関係について検討した . 以下に , 検 討方法および結果について報告する．

\section{2 . 検討の手順}

本検討では，室内試験によりゴム弾性舗装の弾力性 とタイヤ騒音の関係把握を目的に, スチレン・ブタジ ェン・ゴム板(以下：SBR 板という) と多孔質なゴム 弾性舗装材(以下: ゴム弾性という)の静的ばね定数と

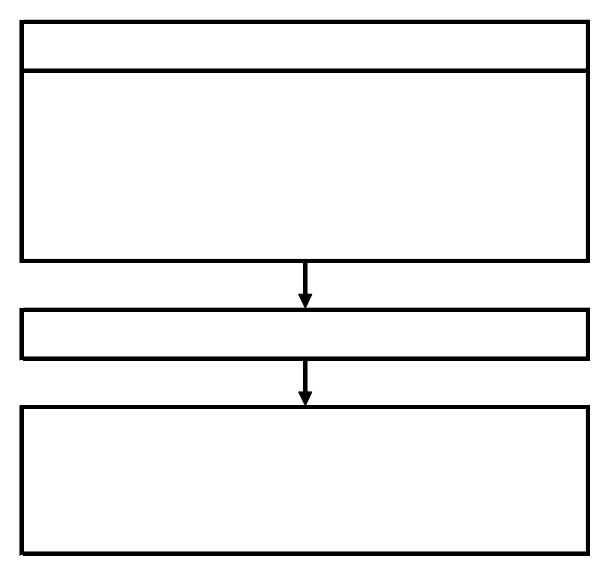

図- 1 検討フロー

タイヤ落下衝突音および衝撃加速度とタイヤ落下衝突 音の関係から，弾力性の影響について検討した . 試験 施工では, 弾力性(軟らかさ, 衝撃緩和性) が実車騒音 やカート騒音・振動の低減効果に及ぼす影響について 検証を行った . 図-1に検討のフローを示す 。 


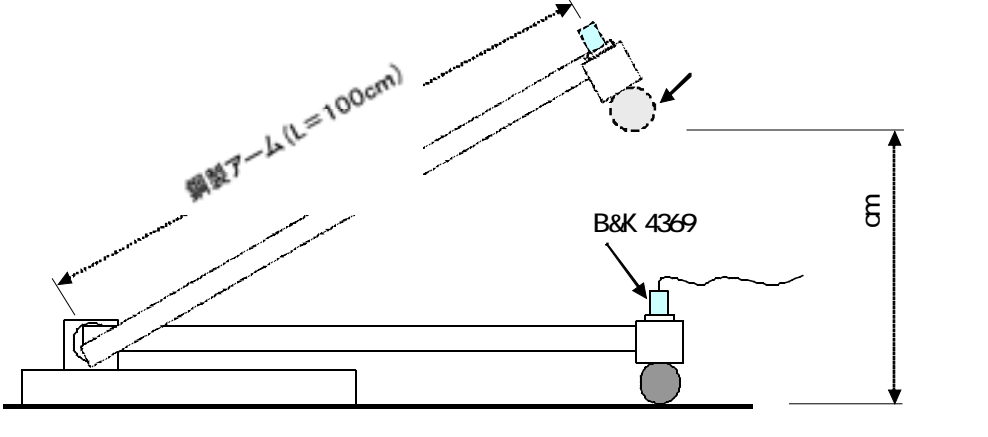

図- 2 衝撃加速度測定装置

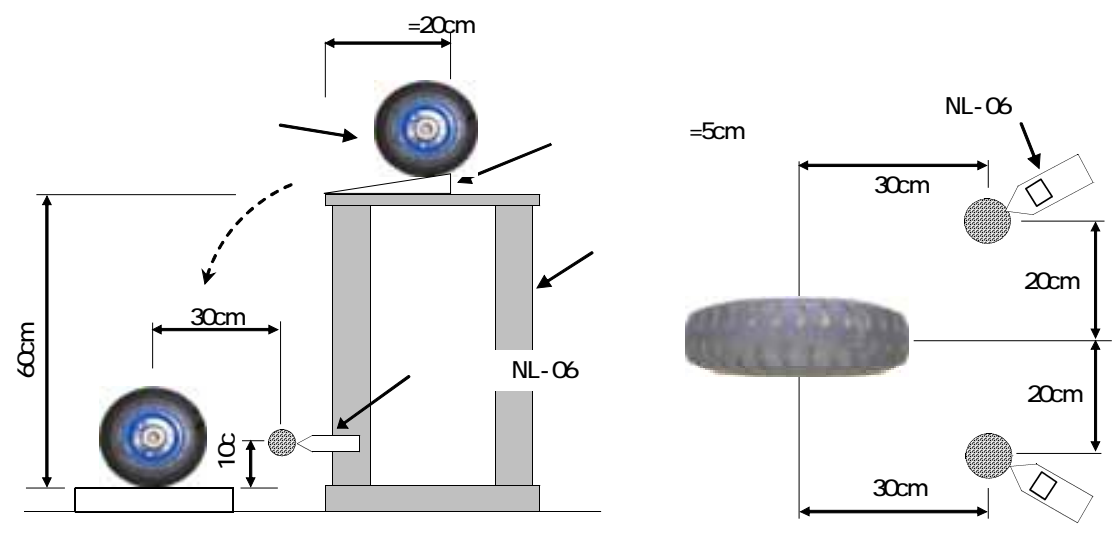

図-3 小型タイヤタイヤ落下試験方法

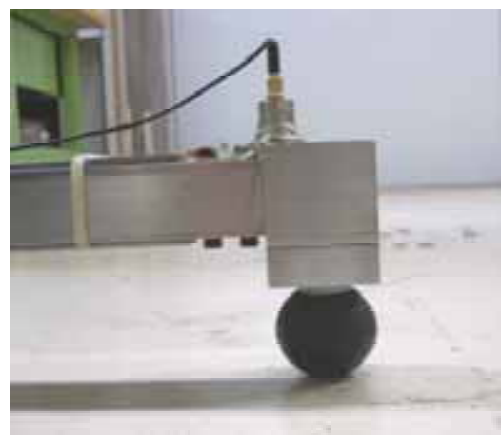

写真- 1 試験装置ゴムヘッド

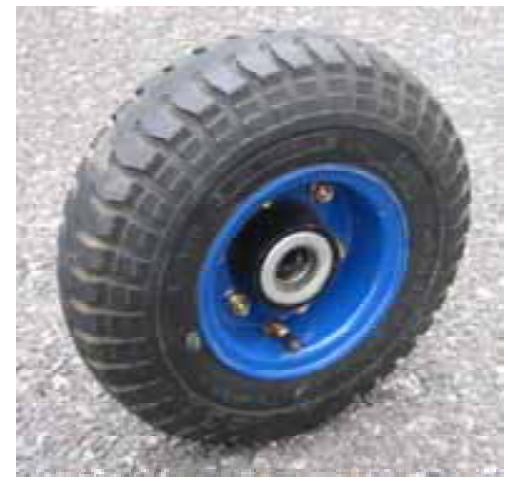

写真- 2 試験タイヤ

\section{3 . 室内実験}

(1) ゴム系弾性舗装材

室内実験に使用したゴム系弾性材料には，ゴム硬度 が $40 ， 60$, 80 で厚さが $15 \mathrm{~mm}$ と $25 \mathrm{~mm}$ の SBR 板およ び最大粒径 $5 \mathrm{~mm}$ のゴムチップと細骨材とバインダ (ウレタン樹脂)の容積配合比率が 56.3 : 18.7 : 25 で， 厚さが $15 \mathrm{~mm}$ と $25 \mathrm{~mm}$, 空隙率 30\%のゴム弾性舗装材 ( 以下, ゴムチップと細骨材の比率が 75:25 の配合を ゴム弾性 G75 という) を用いた .

\section{( 2) 静的ばね定数試験方法}

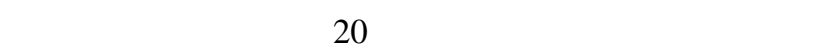
防振ゴムの試験方法 ${ }^{4)}$ に基づいて求めた .なお，試 験に用いた供試体は縦・横 $300 \mathrm{~mm}$, 鋼製貫入棒の直 径は 25.4mm である。また, 試験にあたっては、載荷 速度 $4 \mathrm{~mm} / \mathrm{min}$ で 5 回測定し, 結果を算術平均した。

\section{（3）衝撃吸収性試験方法}

各舗装材の衝撃吸収性を評価する目的で「床衝撃音 発生装置( JIS A1418-2)」を参考に図- 2 , 写真- 1に示す 装置を考案し，20 ㄷおける SBR 板とゴム弾性 G75 について衝撃加速度を測定した . 試験は , 長さ $100 \mathrm{~cm}$ の鋼製アームの先端に, 直径 $35 \mathrm{~mm}$ の市販ドア取っ 手用ゴム球(硬度 60 : タイヤゴム硬度程度) を取り付
け，高さ $30 \mathrm{~cm} よ り$ 自由落下させた時の衝撃加速度を， 先端に取り付けた加速度計 (B\&K4369) で測定するも のである . なお，測定は 3 回行い結果を算術平均した .

\section{（4）タイヤ落下試験方法}

タイヤ落下試験法は, タイヤを一定の高さから供試 体に落下させ，弚の時に発生する夕イヤと路面の衝突 音を測定するもので，排水性混合物の騒音低減効果を 評価できるといわれている5 ${ }^{5}$. 今回 , 過去の研究例を 参考に，ラグパターンの軽量小型タイヤ( タイヤサイ ズ : 5.30-5, 空気圧: $100 \mathrm{kPa}$, 重量 : $3.5 \mathrm{~kg}$ )を用いた簡 易なタイヤ落下騒音発生装置を考案し, 各舗装材の20 ${ }^{\circ} \mathrm{C}$ における SBR 板およびゴム弾性 G75 のタイヤ衝突 騒音ピーク値を 5 回測定した . 小型タイヤ落下試験方 法の概要を図-3に, 試験タイヤを写真- 2に示す.

\section{4. 室内検討結果}

(1) ゴム系弾性材料の硬さと衝撃吸収性の関係

図-4に SBR 板の $20{ }^{\circ} \mathrm{C}$ におけるゴム硬度と静的ばね 定数の関係を示す.SBR ゴム板は，ゴム硬度が大き くなると静的ばね定数も大きくなる関係にある．また， SBR ゴム板の静的ばね定数は，ゴム硬度が同一でも 厚さ $15 \mathrm{~mm}$ と $25 \mathrm{~mm}$ では薄い方が大きく，厚さによ り静的ばね定数が変化する．これらのとから，ゴム系 


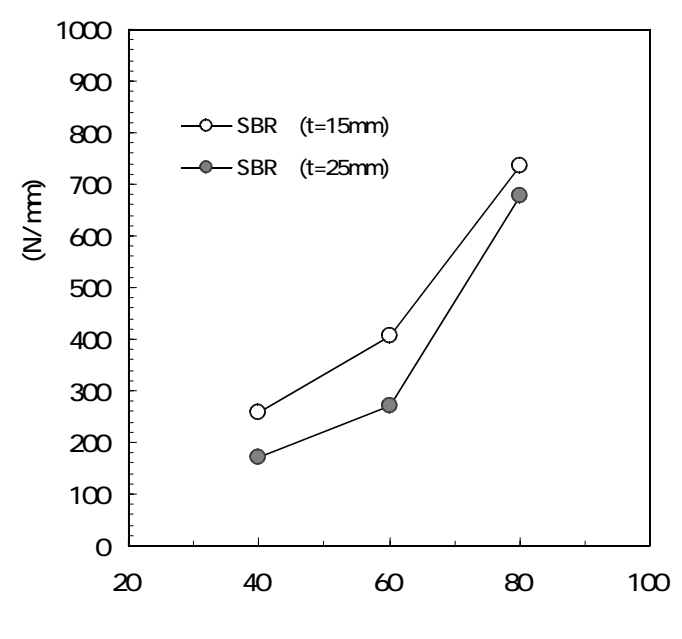

図-4 ゴム硬度と静的ばね定数の関係

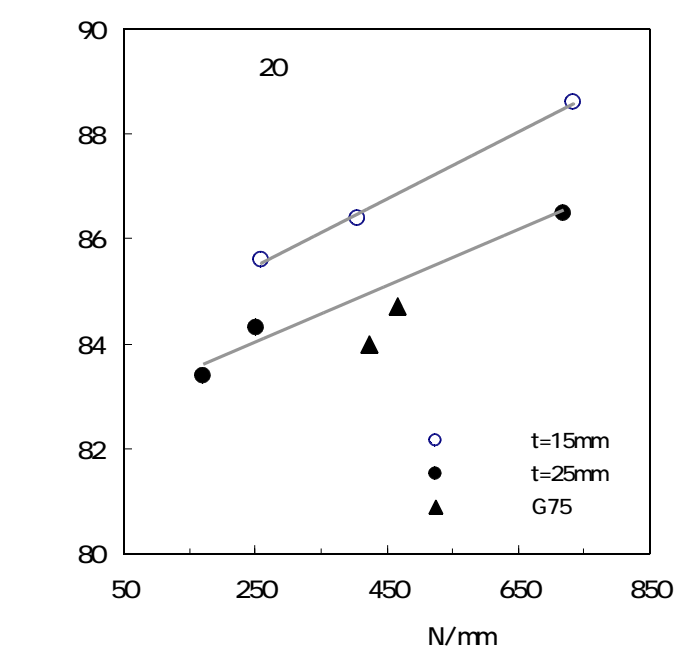

図- 6 静的ばね定数とタイヤ落下衝突音の関係

弾性材料の硬さ評価には, 静的ばね定数を用いること が適当と考える．图-5に，SBR 板とゴム弾性 G75(t=1 $5 \mathrm{~mm}, \mathrm{t}=25 \mathrm{~mm})$ の $20{ }^{\circ} \mathrm{C}$ における衝撃加速度測定結果 を示す . 図より，”静的ばね定数と衝撃加速度の関係 ”は，SBR 板およびゴム弾性 G75 とも，ほぼ同一直 線上にある . また, 静的ばね定数が大きくなるにした がい衝撃加速度も大きくなることから，弾力性の一指 標であるゴム硬度を衝撃加速度で評価できることがわ かった .

\section{（2）タイヤ落下衝突音の評価}

20 ㄷにける SBR 板およびゴム弾性 G75 の”静的 ばね定数とタイヤ落下衝突音の関係”を図-6に，SBR 板の” 衝撃加速度とタイヤ落下衝突音の関係”を図- 7 に示す . 図-6より，”静的ばね定数とタイヤ落下衝突 音”には直線関係が認められ，静的ばね定数が大きく なるにしたがい, タイヤ落下衝突音も大きくなること がわかる.また, 回帰直線から見た SBR 板のタイヤ

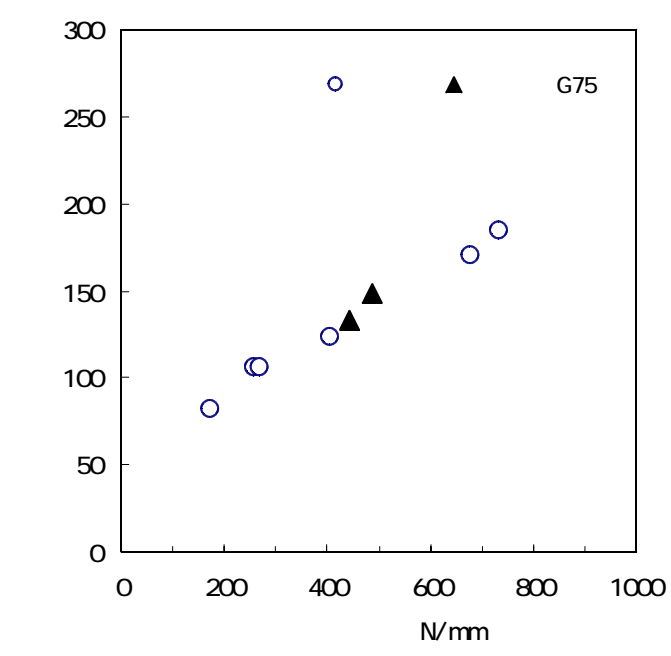

図- 5 静的バネ定数と衝撃加速度の関係

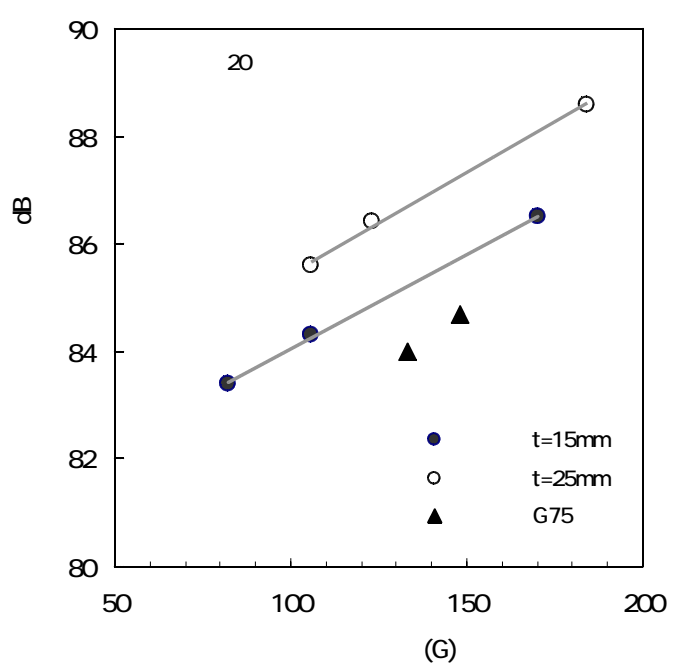

図- 7 衝撃加速度とタイヤ落下衝突音の関係

落下衝突音は, 厚さ $15 \mathrm{~mm}$ と $25 \mathrm{~mm}$ では約 $2 \mathrm{~dB}$ の差 が見られ, 同じ静的ばね定数でも薄いとタイヤ落下衝 突音が大きくなると推察される．また，SBR 板の衝 撃加速度とタイヤ落下衝突音の関係は図-7に示すとお り，”衝撃加速度とタイヤ落下衝突音”にも直線関係 か認められ, 衝撃加速度によりタイヤ落下衝突音の評 価が可能である .

一方，ゴム弾性 G75 タイヤ落下衝突音は図-6，7に 示すとおり，多孔質な舗装材の吸音性により SBR 板 よりさらに小さくなることがわかった .

\section{5 . 試験施工による検証}

\section{(1) 試験施工の概要}

a) 目的

室内試験により，弾力性に富むゴム系弾性材料の硬 さ, 衝撃吸収性およびタイヤ落下衝突音は, 静的ばね 定数や衝撃加速度により評価できることを確認できた． 
表- 1 普通車騒音測定用のゴム弾性舗装

\begin{tabular}{|c|c|c|c|}
\hline \multirow{2}{*}{ 舗装名 } & \multicolumn{3}{|c|}{ 容積配合比 \% ) } \\
\cline { 2 - 4 } & ゴムチップ & 細骨材 & バインダ \\
\hline ゴム弾性G70 & 56 & 24 & 20 \\
\hline ゴム弾性G50 & 40 & 40 & 20 \\
\hline ゴム弾性G30 & 24 & 56 & 20 \\
\hline
\end{tabular}
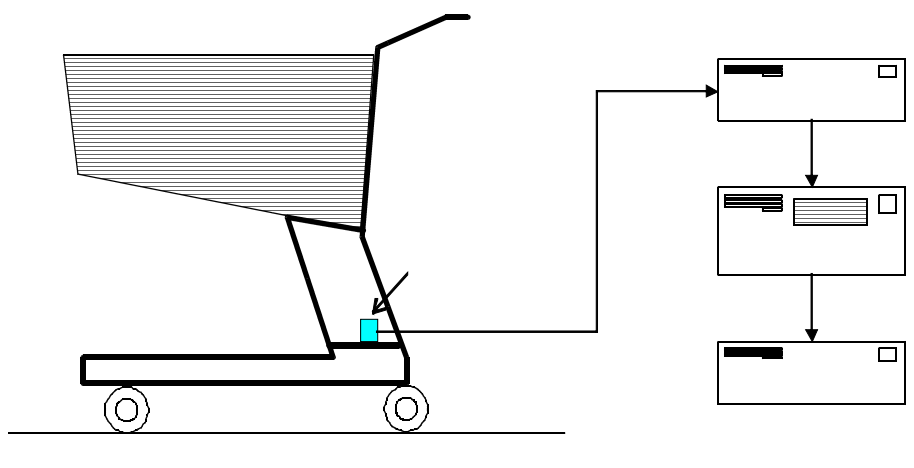

図-9 カートの振動加速度レベル試験方法の概要

そこで, 実際の舗装路面における普通車騒音およびカ 一ト騒音等を測定し, 静的ばね定数や衝撃加速度から 見た効果の検証を試みた .

b) 普通車走行騒音測定用の試験舗装

普通タイヤ騒音の測定に用いた舗装は，ゴム弾性舗 装が, 最大粒径 $5 \mathrm{~mm}$ のゴムチップと細骨材とバイン ダ(ウレタン樹脂)の容積配合比率を変化させた表-1に 示す 3 種類( 空隙率約 $32 \sim 34 \%$ ) とした. また比較用 には, 最大粒径 $13 \mathrm{~mm}$, 厚さ $50 \mathrm{~mm}$ の密粒度アスファ ルト舗装(以下, 密粒(13) という), 最大粒径 $13 \mathrm{~mm}$, 空隙率 $20 \%$ ，厚さ $50 \mathrm{~mm}$ の排水性舖装(以下，排水性 （13）という）を用いた．試験舖装の規模は，ゴム弾性 舗装 G70，G50，G30 が延長 $25 \mathrm{~m}$ ，幅 $3.5 \mathrm{~m}$ ，厚さ $3 \mathrm{~cm}$ ， 密粒 (13) と排水性 (13) が延長 $50 \mathrm{~m}$, 幅 $3.5 \mathrm{~m}$, 厚さ $5 \mathrm{c}$ mである .

c）カート騒音測定用の試験舗装

カート騒音の測定に用いた舗装は, ゴム弾性舗装が 最大粒径 $5 \mathrm{~mm}$ のゴムチップと細骨材とバインダ(ウ レタン樹脂)の容積配合比率を $56.3: 18.7: 25$ (以下, ゴム弾性 G75 という)としたものを，また比較用には， 隣接する密粒(13) を用いた . 各試験舖装の規模は, ゴ 么弾性舗装 G75 が延長 $25 \mathrm{~m}$, 幅 $3.5 \mathrm{~m}$, 厚さ $2.5 \mathrm{~cm}$. 密粒(13)が, 延長 $25 \mathrm{~m}$, 幅 $3.5 \mathrm{~m}$ ，厚さ $5 \mathrm{~cm}$ である.

（2）試験方法

a) 普通タイヤの騒音測定方法

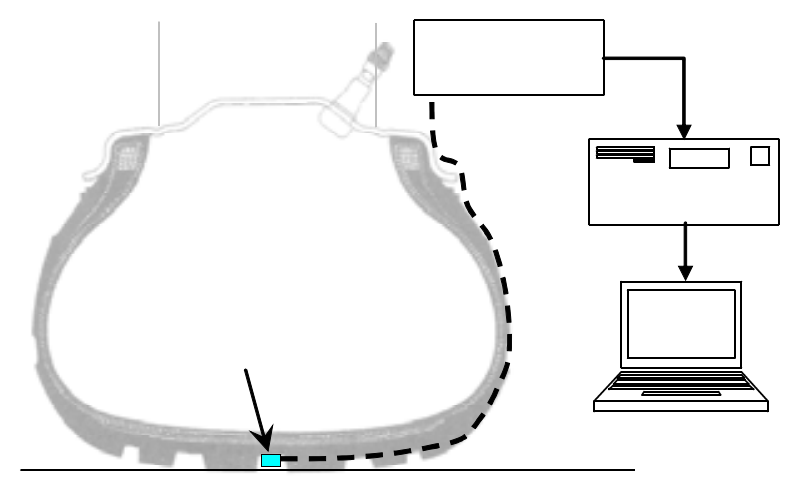

図-8タイヤ側衝撃加速度測定方法の概要

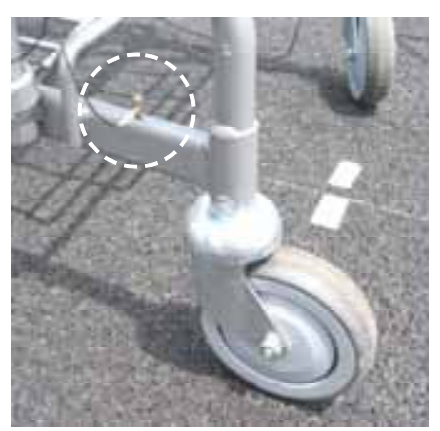

写真- 3 加速度計取付け状況

普通タイヤの騒音測定は通過騒音について行った . 通過騒音は, 普通車( タイヤサイズ : 195/65R14, 空気 圧：196.2kPa，排気量 2000cc) を使用し，舖装中心(車 両中心) から側方 $7.5 \mathrm{~m}$ で，高さ $1.2 \mathrm{~m}$ の地点に騒音計 (NL-06) を設置し，定常走行時( 速度 $50 \mathrm{~km} / \mathrm{h}$ ) の通過騒 音を 5 回測定した .

b) タイヤトレッドの衝撃加速度測定方法

タイヤと路面間の発生音には, タイヤと路面の接触 によるトレッドパターン溝共鳴音 , トレッドパターン 加振音, タイヤ接地摩擦振動音, 路面凹凸によるタイ ヤ加振音，エアポンピング音等がある ${ }^{6)}$. ゴム弾性舗 装は，通常のアスファルト舗装に比へ軟らかいことか ら，タイヤ振動に伴う加振音も低減している可能性が 高いと考えられる．乥こで，タイヤへの衝撃力を測定 するため, 超小型加速度計をタイヤトレッド溝内(サ イズ：195/65R14，空気圧：196.2kPa)に取り付け，ゴ 厶弾性 G50 と密粒(13) を速度 $50 \mathrm{~km} / \mathrm{h}$ (定常走行) で走 行した時の加速度を測定した . 測定方法の概要を図-8 に示す．

c) 普通車試験路面の静的ばね定数および衝撃加速度 の測定方法

各試験路面の静的ばね定数は，現場 CBR 試験装置 の貫入棒直径を $25.4 \mathrm{~mm}$ に変更し, 室内試験と載荷速 度で各 5 回測定した . また, 衝撃加速度は室内試験と 同一の装置を用いて各 5 回測定した . 


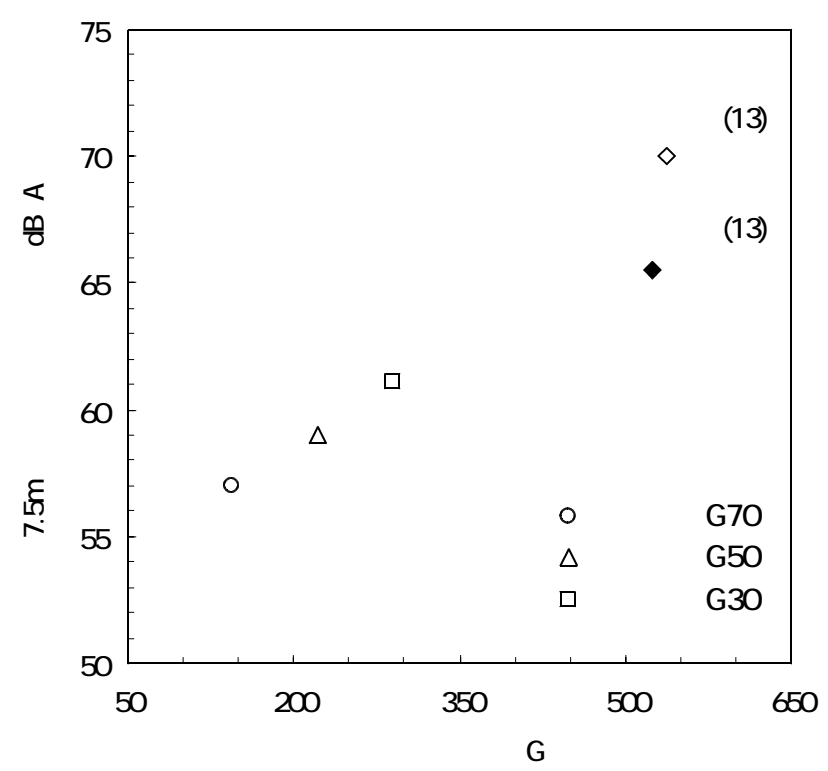

図-10 衝撃加速度と通過騒音レベルの関係

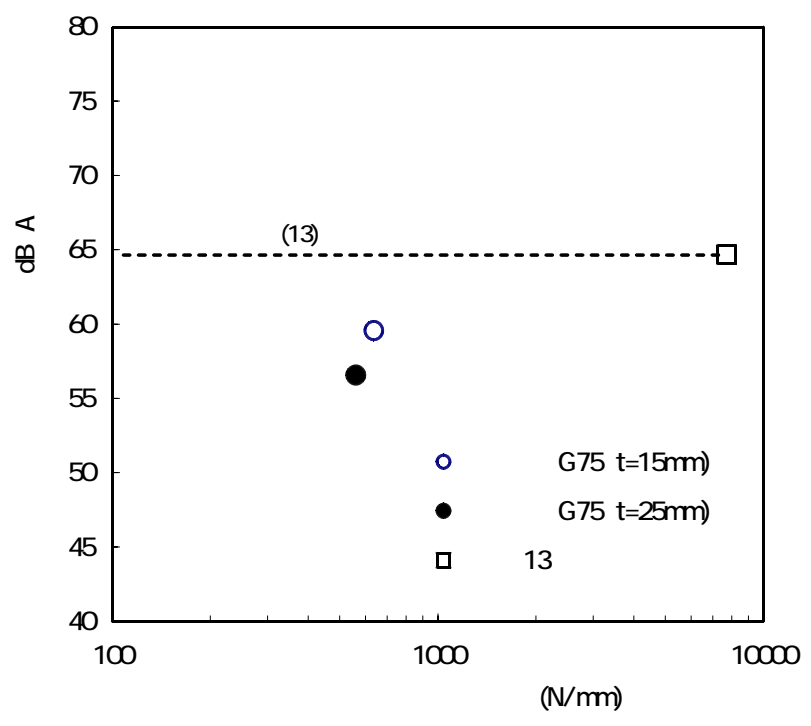

図-13 静的ばね定数とカート騒音值の関係

d) カートの騒音測定方法

カートの騒音レベルは, 走行中心線から側方 $2 \mathrm{~m}$, 高さ $1.2 \mathrm{~m}$ に設置した騒音計(NL-06) を用いて測定した。 測定にあたっては, 走行速度 $4 \mathrm{~km} / \mathrm{h}$ (歩行速度程度)， 無積載状態の大型カート通過騒音ピーク値を, ゴム弾 性 G75( $\mathrm{t}=25 \mathrm{~mm}, \mathrm{t}=15 \mathrm{~mm}$ ) と密粒(13)について各 5 回 計測した。

e) カートの振動加速度レベル試験方法

カートや荷さばき台車がゴム弾性舗装上を走行した 場合には, 密粒 (13) に比べ $10 \mathrm{~dB}$ 以上の騒音低減効果 が得られている ${ }^{3)}$. 乥こで, ゴム弾性 $\mathrm{G} 75(\mathrm{t}=25 \mathrm{~mm}$ ， $\mathrm{t}$ $=15 \mathrm{~mm})$ と密粒 (13) について大型カートの振動レベル を測定し，ゴム弾性 G75 によるカート振動の低減効 果について検証した . 試験は, 超小型の加速度計を力

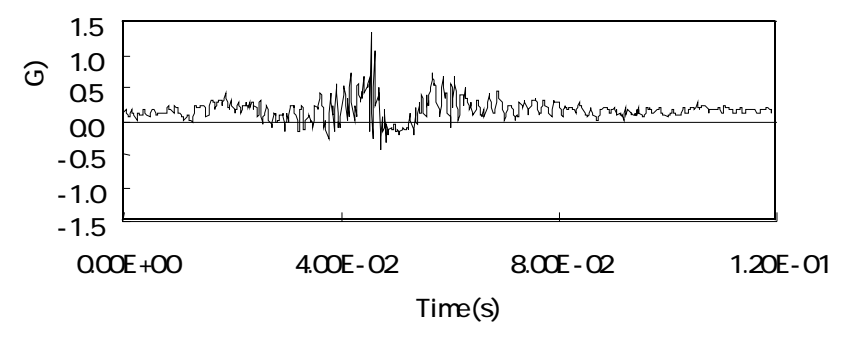

図-11 密粒(13) のタイヤトレッド加速度

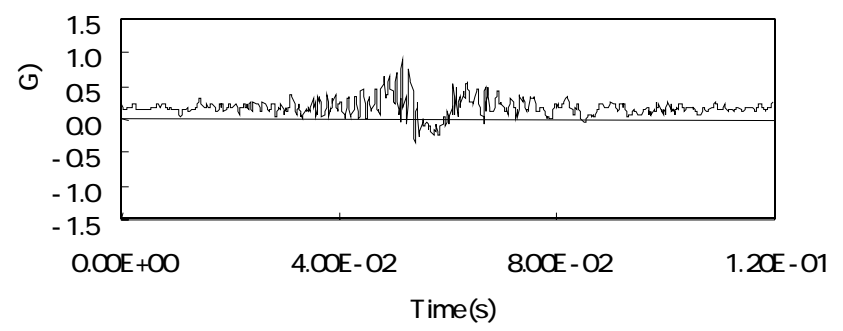

図-12 ゴム弾性 G50 のタイヤトレッド加速度

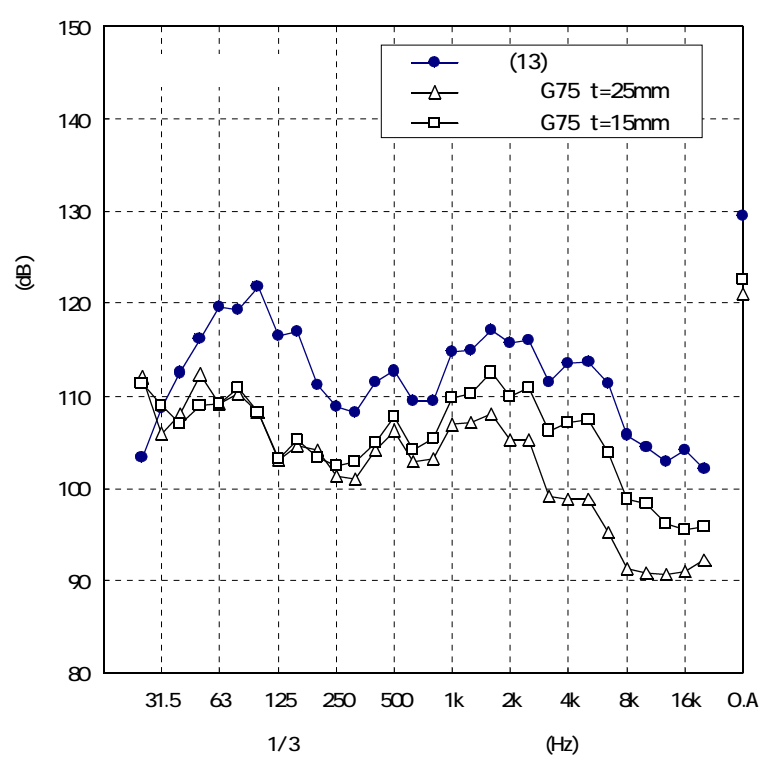

図-14 カート振動加速度の周波数特性

一ト車輪近傍に取り付け, 速度 $4 \mathrm{~km} / \mathrm{h}$ (歩行速度) における振動加速度レベルピーク值を各 5 回測定した 。 図-9に加速度の計測方法の概要を，写真-3にセンサー 取り付け位置を示す。

\section{（3）試験施工結果}

a) 衝撃加速度と普通車騒音の関係

图- 10に衝撃加速度と普通車通過騒音レベル $(7.5 \mathrm{~m}$ 点)の関係を示す . 図より, ゴム弾性舗装は衝撃加速 度が大きい(ゴムチップの配合割合がが小さい)ほど普 通車の通過騒音レベルは大きくなり，ゴム弾性舗装の 衝撃緩和性が通過騒音に影響を与えていることか認め られる．また，密粒(13) と排水性 (13) の衝撃加速度は ほぼ同程度であるが，通過騷音レベルは密粒(13) の約 
$70 \mathrm{~dB}$ に対し，排水性(13) は約 $65 \mathrm{~dB}$ と $5 \mathrm{~dB}$ 小さい． これは排水性(13)の衝撃吸収性によるものではなく， ポーラスな構造による騒音低減効果によると考えられ， 衝撃加速度による排水性(13) の低騒音性評価は適当で ないと考えられる．以上の結果から，ゴム弾性舗装の 騒音低減効果は舗装体の衝撃緩和性が大きく影響して いることが確認できた .

b) タイヤへの衝撃力低減効果

図-11〜12に, 密粒(13) とゴム弾性 G50 を速度 50k $\mathrm{m} / \mathrm{h}$ (定常走行) で走行した時のタイヤトレッド溝に発 生した加速度を示す．図より，密粒(13) の加速度の ピーク値は約 $1.4 \mathrm{~dB}$ であるのに対し，ゴム弾性 G50 の場合は約 $0.8 \mathrm{~dB}$ とほぼ半減しており，ゴム弾性舗装 はタイヤへの衝撃力も低減していることか確認できた . これは, タイヤ騒音の一つであるタイヤトレッドパタ ーン振動音の低減に寄与していると推察される。

c) カート騷音の低減効果

密粒 (13) とゴム弾性 G75( $\mathrm{t}=25 \mathrm{~mm}, \mathrm{t}=15 \mathrm{~mm})$ におけ るカート通過騒音と静的ばね定数の測定結果を図-13 に示す. 図より，密粒 (13) の静的ばね定数は約 $8000 \mathrm{~N}$ $/ \mathrm{mm}$ で, 光の時のカート通過騒音レベルは約 $65 \mathrm{~dB}$ （A）であった．一方，ゴム弾性 G75 の静的ばね定数は， $\mathrm{t}=25 \mathrm{~mm}$ で約 $550 \mathrm{~N} / \mathrm{mm}, \mathrm{t}=15 \mathrm{~mm}$ で $650 \mathrm{~N} / \mathrm{mm}$ と $100 \mathrm{~N} /$ $\mathrm{mm}$ の違いで, カート通過騒音レベルは, $\mathrm{t}=25 \mathrm{~mm}$ で 約 $56 \mathrm{~dB}(\mathrm{~A}), \mathrm{t}=15 \mathrm{~mm}$ で約 $60 \mathrm{~dB}(\mathrm{~A})$ と $4 \mathrm{~dB}(\mathrm{~A})$ の差が 認められた . 以上の結果から , ゴム弾性舗装における カート騒音低減効果は密粒(13) より大きいものの, ゴ 么弾性路面の静的ばね定数により，产の効果には差が あることがわかる .

d) カートの振動低減効果

密粒 (13) , ゴム弾性 G75( $\mathrm{t}=25 \mathrm{~mm}, \mathrm{t}=15 \mathrm{~mm})$ を走行 した際の大型カート振動加速度レベルの $1 / 3$ オクター ブバンド周波数分析結果を図-14に示す.ゴム弾性 G7 5 での振動加速度レベルは, 全周波数帯において密粒 (13)より小さく，弾力性による振動低減効果が確認で きた．また，ゴム弾性 G75 で比較すると， $\mathrm{t}=25 \mathrm{~mm}$ よ り路面の静的ばね定数が大きい $\mathrm{t}=15 \mathrm{~mm}$ の方が振動レ ベルが大きくなることが確認できた .

\section{6 . 結論}

\section{（1）ゴム系弾性材料の硬さと衝撃吸収性}

SBR ゴム板は，ゴム硬度が大きくなると静的ばね 定数も大きくなるが, ゴム硬度が同一の場合でも、厚 さの違いで静的ばね定数が変化する．このことから， ゴム系弾性材料の硬さ評価には, 静的ばね定数を用い ることが適当と考える．また，ゴム系弾性材料の静的 ばね定数と衝撃加速度の間にもほぼ直線関係が認めら
れ，硬さと衝撃緩和性は密接な関係にあることがわか った.

\section{(2) タイヤ落下衝突音の評価}

ゴム系弾性材料の静的ばね定数とタイヤ落下衝突音 の間には直線関係か認められ，静的ばね定数や衝撃加 速度が大きくなるにしたがい，タイヤ落下衝突音も大 きくなることがわった . また, タイヤ落下衝突音は, 厚さや吸音性の影響を受けることがわかった .

\section{（3）衝撃加速度と普通車騒音の関係}

実車が走行した場合のゴム弾性舗装の騒音は，室内 試験と同樣に衝撃加速度で評価できることを確認した . また，ポーラスな構造を有する排水性(13) は, 密粒(1 3) と同等の硬い路面であるにも係わらず通過騒音レべ ルは密粒(13)より約 $4 \mathrm{~dB}$ 小さいことから，排水性(1 3)の低騒音性を衝撃加速度により評価することは適当 でないと考える。

\section{（4）タイヤへの衝撃力低減効果}

ゴム弾性 G50 を走行した際のタイヤトレッド溝内 の発生加速度は，密粒(13) を走行した場合のほぼ $1 / 2$ で, ゴム弾性舗装がタイヤへの衝撃力を低減している ことが確認できた . なお, 今回排水性舗装については タイヤトレッド溝内の発生加速度を測定していないが， タイヤへの衝撃力低減効果を排水性舗装が有している かどうかについても検証する必要があると考える．

\section{（5）カート騒音の低減効果}

ゴム弾性 G75 と密粒(13)におけるカート通過騒音 と静的ばね定数の測定結果から,ゴム弾性 G75 の騒 音レベルは, 密粒(13) に比べ約 $5 〜 9 \mathrm{~dB}(\mathrm{~A})$ 小さくな り，高い騒音低減効果が得られる。また，ゴム弾性 G75 の静的ばね定数が $100 \mathrm{~N} / \mathrm{mm}$ 異なると, カート 通過騒音レベルは約 $4 \mathrm{~dB}(\mathrm{~A})$ 異なることから，ゴム弾 性舗装におけるカート騷音の低減効果は, ゴム弾性路 面の静的ばね定数により差があることがわかった .

（6）カートの振動低減効果

カートの振動加速度の周波数分析から, ゴム弾性 G 75 での振動加速度は全周波数帯において密粒(13)よ り小さく,ゴム弾性舗装の振動低減効果が確認できた .

\section{7 .おわりに}

普通車騒音, カート騒音に影響を与える要因として ゴム弾性舗装の弾力性を取り上げ検討を行った，弚の 結果, ゴム弾性舖装における騒音值は, 静的ばね定数 
や衝撃加速度と高い関係にあり，ゴム弾性舗装の軟ら かさや衝撃吸収性がこれら騒音值に大きく影響してい ることを確認した .なお，ゴム弾性舗装は温度により 硬さか変化すると考えられることから，今後は低温域 おけるデータ収集を行い，ゴム弾性舗装の弾力性と普 通車騒音およびカート騒音との関係をより明確にして いきたい .

\section{参考文献}

1) 小林昭則, 藤田広志, 増田欽司 : ゴムチップ舗装 材の車道への適用に関する検討，(社)土木学会舗 装工学論文集第 5 巻, pp.39-46，2000.

2) 小林昭則, 吉田 武, 寺田 剛：促進載荷試験に
よるゴムチップ舗装の耐久性 , 土木学会第 57 回年 次学術講演会概要集, pp.25-26, 2002.

3) 小林昭則, 平川一成, 島 広志, 丸山暉彦 : ゴム 弾性舗装の駐車場舗装への適用に関する検討， (社) 土木学会舖装工学論文集第 10 巻, pp.153-160， 2005 .

4) 日本規格協会 : 防振ゴムの試験方法(JIS K 6385), 日本工業規格ハンドブック 28-2，p672，2004.

5) 岡部俊幸, 林 信也, 門澤忠雄 : タイヤ落下法によ る低騒音舗装の評価について, 第 23 回日本道路会 議一般論文集，p18-19，1999。

6)（社）日本自動車タイヤ協会：タイヤ道路騒音につ いて, 第 7 版, p30，2004.

\title{
A STUDY ON THE RELATIONSHIP BETWEEN REDUCTION OF TIRE/ROAD NOISE AND ELASTICITY OF RUBBER ELASTIC PAVEMENTS
}

\author{
Akinori KOBAYASHI, Kazunari HIRAKAWA, Hiroshi SHIMA and Teruhiko MARUYAMA
}

As for the rubber elastic pavement, a high noise reduction effect is provided than conventional porous pavement, and what can largely reduce the tire/road noise at the time of a low speed run and the shopping cart noise is found. It is thought that noise reduction effect of rubber elastic pavement is affected by noise absorption characteristics, thickness, the elasticity, impulsive relaxation characteristics of a pavement. In this study, it was examined the influence that the static spring constant as the elastic softness and the impulsive acceleration as impulsive relaxation characteristics of rubber elastic pavement gave to the vehicle tire/road noise and the shopping cart noise. As a results, it was found that the static spring constant and the impulsive acceleration of rubber elastic pavement were related to influence on reduction characteristics of the vehicle tire/road noise and the shopping cart noise. 